\title{
The effect of potassium iodide on the production of acid phosphatase by Sporothrix schenckii
}

\author{
P.S. Grover, Kamlesh Thakur
}

\begin{abstract}
Abstrak
Tujuan penelitian ini adalah untuk mengetahui efek in vitro kalium iodida (KI) pada produksi fosfatase asam dengan mengkarakterisasikan secara lengkap strain S.schenckii yang diisolasi dari seorang pasien dengan sporotrichosis kulit. Enzim fosfatase asam diukur selama 3 fase pertumbuhan S. schenckii, dengan dan tanpa KI yang ditambahkan pada medium kultur dengan 3 konsentrasi berbeda. Pada kontrol dan bahan uji dengan konsentrasi KI yang berbeda, tidak dijumpai efek samping KI pada produksi fosfatase asam, pada fase awal dan "mid-log” pertumbuhan jamur. Sedangkan pada fase eksponensial dari bahan uji tampak penurunan produksi enzim yang bermakna secara statistik dengan kadar KI 0,8\% dan 3,2\%. Aktivitas yang rendah pada kadar KI 0,8\% dan 3,2\% menunjukkan bahwa KI mempunyai efek hambatan pertumbuhan S.schenkii dan menyebabkan penurunan aktivitas enzim. (Med J Indones 2003; 12: 65-8)
\end{abstract}

\begin{abstract}
The present study was undertaken to find out the in-vitro effect of potassium iodide (KI) on the production of acid phosphatase by fully characterized strain of S.schenckii isolated from a patient of Cutaneous Sporotrichosis. The enzyme acid phosphatase was estimated during the 3 phases of growth of S.schenckii, without and with three concentrations of KI incorporated in the culture medium. In the control and in the test proper, with various concentrations of KI, no adverse effect of KI was observed on the production of acid phosphatase in early and mid log phase of fungal growth. Whereas in the exponential phase in test proper, there was a statistical significant decrease in the enzyme production with $0.8 \%$ and $3.2 \%$ of KI. The low activity at $0.8 \%$ and $3.2 \%$ KI indicates that KI has inhibitory effect on the growth of S.schenckii and has led to decrease in the activity of the enzyme. (Med J Indones 2003; 12: 65-8)
\end{abstract}

Keywords: S.schenckii, acid phosphatase, potassium iodide

Sporothrix schenckii (S. schenckii), the etiological agent of sporotrichosis, has world wide distribution. In the state of Himachal Pradesh, a hilly state of India, the existence of this disease has been documented and more than 30 cases of sporotrichosis have been reported in a short span of time. ${ }^{1}$ Very little is known about the pathogenic potential of $S$. schenckii. The enzymes like proteinases, dehydrogenases, phosphatases and transaminases have been studied by various workers. $^{2,3,4}$ Out of these only a few have been regarded to be responsible for the pathogenicity of this fungus. Acid phosphatase had attracted the attention and only a few studies have been done on this aspect. ${ }^{5,6}$ Potassium iodide (KI) has been the drug of choice for the treatment of sporotrichosis since the

Department of Microbiology, Indira Gandhi Medical College, Shimla (H.P.), India recording of this disease. ${ }^{7,8}$ It exact mode of action is not known so far. Probably it has an adverse effect on protein, DNA and RNA metabolism of fungus. Very few studies have been done to find out the effect of KI on the growth of $S$. schenckii. Therefore, it was planned to undertake the present study to estimate the acid phosphatase in S. schenckii and to study the effect of KI on the production of this enzyme in-vitro.

\section{METHODS}

The strain of S. schenckii (22/87) taken for the present study was isolated from a patient of Cutaneous Sporotrichosis. The patient had responded to KI treatment and got fully recovered. The strain was further characterized by intraperitoneal inoculation in a male mice. The classical straus reaction was observed along with typical cigar-shaped bodies and other morphological features of the fungus from the 
peritoneal exudates. It was also subjected to various biochemical reactions for confirmation. This strain was subsequently subcultured and maintained on Sabouraud's Dextrose Agar (SDA) at $4^{\circ} \mathrm{C}$.

\section{Preparation of master culture}

It was preparated by the method of Shadomy et al. ${ }^{10}$ Eight days old culture of $S$. schenckii was obtained from a slope of SDA. It was subculture in $100 \mathrm{ml}$ of Yeast Nitrogen Broth (YND) and incubated at $25^{\circ} \mathrm{C}$ for 8 days. This master culture in YNB was used for subsequent study.

\section{In vitro study}

Of 24 bottles containing $150 \mathrm{ml}$ of $\mathrm{YNB}$, six were taken as control (without KI), designated as group A. Sets of 6 bottles each containing $0.8 \%, 1.6 \%$ and $3.2 \% \mathrm{KI}$ were designated as $\mathrm{B}, \mathrm{C}$ and $\mathrm{D}$ groups respectively. All the bottles were inoculated with $3 \mathrm{ml}$ of master culture and incubated at $25^{\circ} \mathrm{C}$ for 4 days for early $\log$ phase, 8 days for mid log phase and 14 days for peak phase of growth on rotatory shaker at 150 revolutions per minute. On the $4^{\text {th }}, 8^{\text {th }}$ and $14^{\text {th }}$ day, contents of each bottle were filtered through sintered glass filter, washed thrice with ice cold normal saline, dried and weighed. The weighed tissue was homogenized and $10 \%$ homogenate prepared with ice cold distilled water. This $10 \%$ homogenate was used for enzyme assay.

\section{Determination of acid phosphatase}

It was done by the method described by King EJ and Jegatheesan. ${ }^{11}$ In the test proper $(\mathrm{T})$, one $\mathrm{ml}$ of citrate buffer and $1 \mathrm{ml}$ of phenol of concentration of 1 $\mathrm{mg} / 100 \mathrm{ml}$ mixed in a test tube and placed in water bath at $37^{\circ} \mathrm{C}$ for 3 minutes. Then $0.2 \mathrm{ml}$ of $10 \%$ homogenate was added, mixed gently and incubated at $37^{\circ} \mathrm{C}$ for 60 minutes. The reaction was stopped by addition of $1 \mathrm{ml}$ of $0.5 \mathrm{~N}$-sodium hydroxide. In the control tube (A) $1 \mathrm{ml}$ of citrate buffer, $1 \mathrm{ml}$ of phenol and $1 \mathrm{ml}$ of $0.5 \mathrm{~N}$-sodium hydroxide were mixed well and then $0.2 \mathrm{ml}$ of homogenate was added. In the standard tube (S), $1 \mathrm{ml}$ of buffer, $1 \mathrm{ml}$ of water, $1 \mathrm{ml}$ of $0.5 \mathrm{~N}$-sodium hydroxide and $0.2 \mathrm{ml}$ of standard phenol solution of concentration of $1 \mathrm{mg} / \mathrm{ml}$ were mixed together. In the blank (B), $1.2 \mathrm{ml}$ of buffer, 1 $\mathrm{ml}$ of water and $1 \mathrm{ml}$ of $0.5 \mathrm{~N}$-sodium hydroxide and
$0.2 \mathrm{ml}$ of standard phenol solution of concentration of $1 \mathrm{mg} / \mathrm{ml}$ were mixed together. In the blank (B), $1.2 \mathrm{ml}$ of buffer, $1 \mathrm{ml}$ of water and $1 \mathrm{ml}$ of $0.5 \mathrm{~N}$-sodium hydroxide were mixed together. Then in all the tubes, $1 \mathrm{ml}$ of $0.5 \mathrm{~N}$-sodiumbicarbonate was added followed by $1 \mathrm{ml}$ of 4 -amino antipyrine solution and $1 \mathrm{ml}$ of potassium ferricyanide solution. The reddish brown colour produced by the reaction was immediately compared colorimeterically with Ilford 624 green light filter. The phenol in the test proper was calculated in $\mu \mathrm{gm}$ per $\mathrm{mg}$ weight of homogenate by the following formula :

$\frac{\mathrm{T}-\mathrm{A}}{\mathrm{S}-\mathrm{B}} \times \frac{10 \mu \mathrm{gm} \mathrm{x} \text { vol. of homogenate }}{0.2 \mathrm{ml}} \times \frac{1}{\text { Wt of tissue (mg) }}$

\section{Expression of enzyme}

The enzyme acid phosphatase was expressed in $\mu \mathrm{gm}$ of phenol liberated per $\mathrm{mg}$ of tissue per hour at $37^{\circ} \mathrm{C}$.

\section{STATISTICAL METHOD}

The statistical evaluation was done by student $\mathrm{T}$ test.

\section{RESULTS}

Table 1,2,3 depicts the activity of enzyme acid phosphatase in control (Group A, without KI) and in groups $\mathrm{B}, \mathrm{C}, \mathrm{D}$ with $0.8 \%, 1.6 \%$ and $3.2 \%$ concentrations of KI respectively on $4^{\text {th }}, 8^{\text {th }}$ and $14^{\text {th }}$ day of incubation. Six observations were available in each group.

Table 1. Estimation of enzyme acid phosphatase observed on $8^{\text {th }}$ day

( $\mu \mathrm{g}$ of phenol liberated per $\mathrm{mg}$ of tissue per hour at $\left.37^{\circ} \mathrm{C}\right)$

\begin{tabular}{lccccccc}
\hline $\begin{array}{l}\text { Concen- } \\
\text { tration } \\
\text { of KI } \\
(\mathrm{gm} \%)\end{array}$ & I & II & III & IV & V & VI & Mean \\
\hline Nil & 17.16 & 17.82 & 16.81 & 16.19 & 17.32 & 17.02 & $17.05 \pm .20$ \\
control & & & & & & & \\
$0.8 \%$ & 17.31 & 19.96 & 16.98 & 19.48 & 18.89 & 17.36 & $18.23 \pm 0.40$ \\
$1.6 \%$ & 19.88 & 20.06 & 18.94 & 18.12 & 23.50 & 22.41 & $20.36 \pm 0.70$ \\
$3.2 \%$ & 21.15 & 19.86 & 17.71 & 23.87 & 21.84 & 29.46 & $21.62+152$ \\
\hline
\end{tabular}


Table 2. Estimation of enzyme acid phosphatase observed on $4^{\text {th }}$ day

( $\mu \mathrm{g}$ of phenol liberated per mg of tissue per hour at $\left.37^{\circ} \mathrm{C}\right)$

\begin{tabular}{lccccccc}
\hline $\begin{array}{l}\text { Concen- } \\
\text { tration } \\
\text { of KI } \\
(\mathrm{gm} \%)\end{array}$ & I & II & III & IV & V & VI & Mean \\
\hline Nil & 25.31 & 27.32 & 28.05 & 25.93 & 26.55 & 26.41 & $26.42 \pm 0.37$ \\
control & & & & & & & \\
$0.8 \%$ & 35.62 & 38.00 & 41.21 & 34.92 & 23.83 & 23.12 & $32.82 \pm 2.70$ \\
$1.6 \%$ & 31.30 & 35.81 & 33.14 & 33.14 & 31.97 & 33.01 & $33.13 \pm 0.72$ \\
$3.2 \%$ & 34.58 & 34.78 & 33.95 & 33.95 & 32.79 & 28.80 & $33.35 \pm 0.84$ \\
\hline
\end{tabular}

Table 3. Estimation of enzyme acid phosphatase observed on $14^{\text {th }}$ day

( $\mu \mathrm{g}$ of phenol liberated per $\mathrm{mg}$ of tissue per hour at $\left.37^{\circ} \mathrm{C}\right)$

\begin{tabular}{lccccccc}
\hline $\begin{array}{l}\text { Concen- } \\
\text { tration } \\
\text { of KI } \\
(\mathrm{gm} \%)\end{array}$ & I & II & III & IV & V & VI & Mean \\
\hline Nil & 77.91 & 76.01 & 68.24 & 64.92 & 28.53 & 98.73 & $67.51 \pm 5.91$ \\
control & & & & & & & \\
$0.8 \%$ & 54.52 & 71.82 & 29.84 & 8.92 & 91.26 & 35.72 & $48.61 \pm 7.63$ \\
$1.6 \%$ & 57.82 & 63.51 & 77.48 & 87.00 & 53.48 & 80.71 & $70.92 \pm 2.41$ \\
$3.2 \%$ & 26.01 & 43.18 & 38.12 & 52.10 & 52.01 & 28.01 & $37.90 \pm 5.63$ \\
\hline
\end{tabular}

\section{Fourth day}

In control (group A), the activity of enzyme varied from 16.19 to $17.82 \mu \mathrm{gm} / \mathrm{mg}$ of tissue. The mean was $17.05 \pm 0.20 \mu \mathrm{gm} / \mathrm{mg}$.

In group B $(0.8 \% \mathrm{KI})$, the activity varied from 16.98 to $19.96 \mu \mathrm{gm} / \mathrm{mg}$ with mean value of $18.23 \pm 0.70$ $\mu \mathrm{gm} / \mathrm{mg}$.

In group C $(1.6 \% \mathrm{KI})$, it varied from 18.12 to 23.50 $\mu \mathrm{gm} / \mathrm{mg}$ with mean of $20.36+0.70 \mu \mathrm{gm} / \mathrm{mg}$ and $\mathrm{t}$ value 6.12 .

In $3.2 \% \mathrm{KI}$ (Group D), the activity varied from 17.71 to $23.86 \mu \mathrm{gm} / \mathrm{mg}$ with mean $21.62 \pm 1.52 \mu \mathrm{gm} / \mathrm{mg}$ and $t$ value of 2.98 .

\section{Eight day}

In Group A, activity of enzyme varied from 25.31 to $28.05 \mu \mathrm{gm} / \mathrm{mg}$ with mean of $26.42 \pm 0.37 \mu \mathrm{gm} / \mathrm{mg}$. In group B, activity of enzyme ranged from 23.12 to $41.21 \mu \mathrm{gm} / \mathrm{mg}$ with mean of $32.81 \pm .70 \mu \mathrm{gm} / \mathrm{mg}$ and $\mathrm{t}$ value $=2.62$.
In group C, activity varied from 30.51 to $35.81 \mu \mathrm{gm} / \mathrm{mg}$ with mean of $33.13 \pm 0.72 \mu \mathrm{gm} / \mathrm{mg}$ and $\mathrm{t}$ value 8.31 .

In group D, activity ranged from 28.80 to $34.78 \mu \mathrm{gm} / \mathrm{mg}$ with mean, $33.35 \pm 0.84 \mu \mathrm{gm} / \mathrm{mg}$ and $\mathrm{t}=7.61$.

\section{Fourteenth Day}

The activity of enzyme in group A, varied from 28.53 to $89.73 \mu \mathrm{gm} / \mathrm{mg}$ with mean, $6751 \pm 5.97 \mu \mathrm{gm} / \mathrm{mg}$. In group $B$, wide range of enzyme activity was observed which varied from 8.92 to $91.26 \mu \mathrm{gm} / \mathrm{mg}$ with mean of $48.61 \pm 7.63 \mu \mathrm{gm} / \mathrm{mg}$ and $\mathrm{t}$ value $=1.76$. In group $\mathrm{C}$, the value of enzymatic activity varied from 53.48 to $87.01 \mu \mathrm{gm} / \mathrm{mg}$ with mean of $70.92 \pm$ $2.41 \mu \mathrm{gm} / \mathrm{mg}$ and $\mathrm{t}=0.55$.

In group D, it ranged from 26.01 to $52.10 \mu \mathrm{gm} / \mathrm{mg}$ with means value of $37.90 \pm 5.63 \mu \mathrm{gm} / \mathrm{mg}$ and $\mathrm{t}=1.56$.

\section{DISCUSSION}

The enzyme acid phosphatase is ubiquitous among yeast and yeast like fungi. The acid phosphatases of $S$. schenckii have been identified in both yeast and mycelial forms by many workers. ${ }^{5,6,12,13} \mathrm{KI}$, a drug useful in all forms of sporotrichosis has been used insce $19^{\text {th }}$ century but its mode of action is not understood exactly so far. ${ }^{8}$ Various hypotheses have been postulated in this regard. Iodides may act by enhancing defence mechanisms. These may be due to enhanced body's immunological or non immunological tissue response to infection, increase in vascularity, action of proteolytic enzymes, decrease in cyclic AMP which play role in inhibition of fungal growth in vivo and adverse effects on protein, RNA and DNA metabolism of fungus. ${ }^{7,9,14,15}$ In the present study, the enzyme acid phosphatase was estimated on $4^{\text {th }}, 8^{\text {th }}$ and $14^{\text {th }}$ day of incubation to include various phases of growth i.e. early $\log$, mid $\log$ and exponential phase of growth. The values of enzyme activity increased from $4^{\text {th }}$ to $8^{\text {th }}$ day in control as well as in all KI groups. Even on $4^{\text {th }}$ day, with increasing concentration of KI $(0.8 \%$ to $3.2 \%)$, there has been increase in the acitivty of enzyme as compared to control and being statistically significant $(\mathrm{P}<0.05)$. On $8^{\text {th }}$ day of incubation, the activity of enzyme was found to be greater as compared to $4^{\text {th }}$ day in control group which is also statistically significant $(\mathrm{P}<0.05)$. Thus, with the increasing concentration of KI $(0.8 \%-3.2 \%)$, there has been increase in the activity of enzyme decreased at $0.8 \%$ and $3.2 \%$ of $\mathrm{KI}$, being statistically significant $(\mathrm{P}<0.05)$ as compared to control. It was 
found high at $1.6 \% \mathrm{KI}$ though the change being statistically insignificant $(\mathrm{P}>0.05)$. The low activity of enzyme at $3.2 \% \mathrm{KI}$ indicates that $\mathrm{KI}$ has inhibitory effect on the production of acid phosphatase. During the exponential phase of growth, the studies on the effect of KI on the growth of S. schenckii in-vitro are scarce to be found Known Chung ${ }^{16}$ has stated that $S$. schenckii can grow up to $10 \%$ concentration of KI but the author is silent about the degree of the growth. None has evaluated the acid phoshatase or other growth parameters. Another study revealed $1.6 \%$ and $6.4 \%$ concentration of $\mathrm{KI}$ as minimum inhibitory concentration (MIC) and minimum inhibitory fungicidal (MIF) concentration for $S$. schenckii after 6 days and 30 days of incubation respectively.

To conclude, there was no adverse effect of various concentration of $\mathrm{KI}$ on the production of acid phosphatase in early log phase. On the contrary it showed an increased level of enzyme which is statistically significant. The same picture was observed on the $8^{\text {th }}$ day. However, in the exponential phase of the growth $\left(14^{\text {th }}\right.$ day), there was decrease in the enzyme production with concentration of $0.8 \%$ and $3.2 \%$ of KI which is statistically significant. The low activity of enzyme at 3.2\% KI proves that KI has inhibitory effect on the growth of $S$. schenckii. This is very high concentration to be achieved in-vivo even by maximum recommended therapeutic doses. In body, other defence mechanisms may also have an interplay. Thus, $\mathrm{KI}$ in achievable serum concentration alongwith other defence factors may reduce the acid phosphatase production in order to achieve a clinical cure.

\section{CONCLUSION}

There is a significant decrease in the activity of enzyme acid phosphatase at $3.2 \%$ of KI on the $14^{\text {th }}$ day of incubation, probably due to the inhibitory effect of KI on the growth of S. schenckii. This effect along with other defence mechanisms of the body may be the mode of action of KI in the treatment of sporotrichosis.

\section{Acknowledgement}

Contributions of late Dr. Deepak Malhotra, MD, towards the completion of this study is duly acknowledged.

\section{REFERENCES}

1. Singh P, Sharma RC, Gupta ML and Mahajan VK. Sporotrichosis in HP (India). Ind J Med Sci 1983;7(6):101-3.

2. Coudry MR, Canevasaion G and Merer M. Characterization of a cellobiose dehydrogenase in cellulytic fungus sporotrichum thermophile Biochem J. 1982;203(1):77284.

3. Erikson K and Petterson Z. Purification and partial characterization of two acid proteases from the white rot fungus sporotrichum pulverulentum: Eur $\mathrm{J}$ Biochem 1982;124(3):635-42.

4. Tsuboi R, Sanda T, Takawuk and Ogusa H. Isolation and properties of extracellular proteinases from Sporothrix schenckii. J Bacteriol 1987;169(9):4104-9.

5. Arnold WN and Garrison RG. Kinetic limitations on trapping at nascent phosphate for cytochemical localization of yeast acid phosphatase. Current Microbiology, 1981;5:57-60.

6. Garrison Robert $\mathrm{G}$ and Arnold Wilfered N. Cytochemical localization of acid phosphatase in dimorphic fungus $\mathrm{S}$. schenckii. Current Microbiol, 1983;9(5):253-7.

7. Horio T, Danno K, Okamoto H, Miyachi Y, Furukava F, Imamura S. Treatment of erythematous dermotosis with potassium iodide. J Dermatol 1981: 8(6):499-505.

8. Sterling JB, Heymann WR. Potassium iodide in dermatology: a $19^{\text {th }}$ century drug for the $21^{\text {st }}$ century uses, pharmacology, adverse effects and contraindications. J Am Acad Dermatol 2000: 43(4):691-7.

9. Kaistha N. Effect of Potassium Iodide on the growth of S. schenckii in-vitro. Thesis submitted to HP University (India), 1990.

10. Shadomy S, Espinel Ingroff A and Paxton L. Laboratory methods in Medical Mycology. 1978: $4^{\text {th }}$ Ed. P. 173. US Department of Health Education and Welfare, Public Health Services Centre for Disease Control, Atlanta Georgia.

11. King EJ, Jegathecsan KA. Determination of acid phosphatase Journal of clinical pathology 1959;12:85-9.

12. Arnold WN, Mann LC, Sakai KH, Garrison RG, Coleman PD. Acid phosphatases of sporothrix schenckii. J Gen Microbiol 1986;132 (Pt12):3421-32.

13. Arnold WN, Mann LC, Garrison RG. Media-induced departures from the usual, temperature-dependent cell of Sporothrix schenckki and concomitant changes in the acid phosphatase isoenzyme patterns. Microbios 1987;52(212213):161-71.

14. Hachisuka H and Sasai Y. Subpopulation of lymphocytes in the infilterate of experimental sporotrichosis. Mycopatholgia, 1980 July 31;71(3):167-9.

15. Lehninger AL. Proton and electron charge translocation in mitochondrial energy transduction. Adv Exp Med Bio. 1982;148:171-86.

16. Kwon Chung KJ. Sporotrichosis. In: Kwon Chung KT, Bennett JE (eds) Medical Mycology. Lea and Febiger. Malvern, Pennsylvania USA, 1992;707-24. 